\title{
The Storytelling Method Based on Local Wisdom on Moral Values of 5-6 Years Old Children
}

\author{
Nurhayati, Amrullah, Fitriana, Sita Awalunisah \\ Department of Early Childhood Education \\ Tadulako University \\ Palu, Indonesia \\ nurhayatipauduntad@gmail.com
}

\begin{abstract}
Storytelling method based on local wisdom is one of the favored methods of teaching children. The purpose of using this method is to stimulate children's development, one of which is the child's moral value. Children's moral values are very important to stimulate because moral values are very important in a child's life. However, most teachers use more conventional methods to teach so that this method is less applied as a teaching method especially in schools where teachers are more concerned with academics. This article presents a teaching method using local wisdom-based storytelling methods to stimulate children's moral values. The study design used a quasi-experimental pretest-posttest non-equivalent control group design. Data collection used observation and compared with the -t test in the experimental group and the control group. The results show effective storytelling methods applied as children's learning methods to stimulate children's moral values.
\end{abstract}

Keywords—-storytelling methods; local wisdom; moral values

\section{INTRODUCTION}

Education for children at an early age is the basis for determining the character of Indonesian people in the life of the nation. Early childhood education is a human resource development strategy that must be seen as a central point considering the formation of national character and the reliability of human resources are determined by how to grow from early childhood. Early age is an important period, because the experience experienced by children in the early stages of growth and development will have an impact on their lives in the future. An important aspect that is very influential on a child's future life is the child's moral value. This is supported by research conducted by explaining that people's lives depend on the morality of good individuals and children must obtain sufficient moral knowledge and care for others [1]. Supporting previous research that families are often regarded as the foundation of moral learning in Indonesian society, are responsible for caring for and caring for children, and passing morality to children [2]. So the moral value of children is very important to develop in the lives of children to face the next life. But the moral value of children will not develop properly without any treatment from parents, teachers and the surrounding environment because children get values about the moral values of children. These embedded values will later become the conscience of parents to always help and look after others. Therefore, it is very necessary to treat the Early Childhood Education institutions and those around children to increase children's moral values.

For the sake of efforts to develop aspects of early childhood development, optimal methods and learning are needed because learning is very important to stimulate the development of children [4]. The learning and development of early childhood is very closely related, because without learning children cannot develop properly. But in fact there are still many teachers who are still not optimal in their teaching, one of the problems is the learning method applied by the teacher is still very minimal and monotonous. The statement is supported by research findings that state that learning in Indonesia is still not optimal, it is supported by the use of media or the procurement of media in schools is still incomplete and there are still many teachers who are not professional or mastering pedagogically in teaching [5]. The same thing was also found by the Judge arguing that there were still many teachers who were less professional in teaching and the treatment and habits of the learning methods used were still considered monotonous and it was found that teachers could not understand the character of children so that early childhood education teachers were advised to understand character of children in teaching and professional pedagogically because it involves childhood Indonesia so to attract the attention of children in learning teacher must understand the character of children in learning and teaching methods used in teaching should be varied so that children are not bored and tired to follow the teaching and learning process [6]. In addition, the research conducted by Sheridan also suggested that the learning process in early childhood education was still monotonous and only focused on the teacher. In general, the media used for the learning process has not varied and learning has not been through playing [7].

Based on these findings, the learning of early childhood education in Indonesia is still far from optimal because playing is not yet a strategy or vehicle for children's learning and the learning methods used have not varied. The implementation of learning in early childhood is more focused on academic activities and ignores play activities as an erroneous practice of early childhood education. The most done thing is the teacher teaches by explaining and students learn through listening and the child is asked to work or write on the work sheet of the child so that the child does not 
communicate and interact with others. In accordance with the preliminary observational data in some kindergartens in Palu City, there are still many children who rebel with their teachers and parents, do not care about other friends and are less than the child's developmental achievements. This is interesting researchers to examine the moral value of children by testing the theory of storytelling based on local wisdom to improve children's moral values.

Storytelling directly from oral supports learning and development of young children, different when reading picture stories from books [8]. This gives children the opportunity to exercise their imagination, communicate effectively, improve their social literacy, and build communities in different ways. Besides that children together make direct eye contact without books between us. We read each other's faces and emotions (such as giving each other back and forth), matching facial, vocal and physical expressions. If I suddenly jumped up or raised my voice, the children's eyes widened and they gasped. If I start whispering, they bend forward and approach. Listening and responding are direct forms of communication that create a level of intimacy, empathy, and unity [9]. Storytelling activities have an impact on children's interpersonal relations, pigeons, and their own uniqueness. Agosto [12] explains that storytelling stimulates sympathetic responses and causes children to think more deeply about the child's social world. When children listen to stories and then discuss them, children begin to identify cultural norms and standards so they are able to explore their own lives through the story itself. In addition, the story provides a model for children to create relationships between children and teachers. Anak and Dini [13] also argue that the stories chosen by teachers and parents are stories that can develop children's moral values, not those that contain other elements, such as fear. Finally, storytelling provides an educational environment that helps children develop individual perspectives.

Based on the theory above, the moral values of children can be developed with various stories that contain moral messages in it. In this case, it is related to local wisdom, so folklore is chosen which contains moral messages and can be understood by children.

Local wisdom is the tradition of the community or habits carried out by the local community of ideas, values or views from a place that has a wise and good value that is followed and trusted by the community in a place and has been followed for generations [14]. Furthermore, the cultural sphere, the physical dimensions of local wisdom there are several aspects including 1) traditional ceremonies 2) cultural heritage 3) natural tourism 4) traditional transportation 5) traditional games 6) cultural infrastructure 7) traditional clothing 8) cultural heritage 9) museum 10) cultural institutions 11) arts 12) village culture 13) crafts and arts 14)

folklore 15) children's toys and puppets [15]. Mungmachon said that "local wisdom is the basic knowledge gained from living in balance with nature", which means that local wisdom is the basic knowledge gained from living in balance with nature [16]. Local wisdom can be concrete and abstract, but the most important thing is experience and truth that can be obtained in life and respect for the elders. Keeping the balance and preservation of nature together means that we have safeguarded local wisdom. $\mathrm{K}$ then emphasizes that local wisdom as selected knowledge and values and has truth values that are still valid in a society that provides spirit and strength in community development [15]. The value of local wisdom possessed by each community makes each region have its own identity in showing the characteristics of each region itself. Furthermore, explaining local wisdom can be understood as values that apply in society, namely the values that are believed to be true and become a reference in everyday behavior in the local community [17].

Local wisdom is mutual respect between each other, mutual respect between brothers and sisters to prevent the occurrence of problems in the family, Indonesian local wisdom is a legacy inherited from generations to maintain harmony between humans and nature and humans and humans, maintaining kinship between neighbors [18]. Furthermore, in the International Chronicle of the Journal for Historical Studies, it is explained that local wisdom is a form of expression of ethnicity in each region, from which these people carry out the activities they do according to ideas and finally produce certain works [19]. For example, the beautiful Borobudur and Prambanan temples, vernacular houses, the subak water system in Bali rice fields, and batik are world famous cultural heritage. This statement then shows that local wisdom from the depths of the culture of Indonesian society is a complication of ethnic culture and the process expressed in the learning process. Local wisdom is a system of communal communities not individuals that are integrated in the social processes that exist in society.

Characteristics of local wisdom described as follows: (1) local wisdom must incorporate policies that teaches knowledge about ethics and moral values; (2) local wisdom must teach people to love nature, not destroy it; (3) local wisdom must come from older community members. In addition, local wisdom is presented in various forms, through people's minds, work, ways of life, and social values [20]. The problem is that local knowledge is usually not officially published and promoted. As a result, it is difficult for people to learn and use this type of knowledge.

The key indicators or indicators that characterize the value of local wisdom include: (a) local wisdom is knowledge that originates from a community that is still growing and is considered positive for community development, (b) contains many values that content can be developed dynamically such as aesthetic values, ethics, intellectual, skills, unity and unity and unity, and kinship, (c) local ideas or ideas that can develop the local culture, and (d) include local government policies in community development in the area and community cohesiveness to live harmoniously in pluralistic resources [21]. Local wisdom as the strength of moral and spiritual ethics in the local community.

a) Local wisdom can be used as a source of inspiration for the educational process. 
b) Local wisdom as insurance or guarantee of a harmoniousdynamic-integrative life as a form of human consciousness as individual beings and also social beings.

The characteristics of local wisdom are as follows:

a) Having the ability to control

b) Is a fortress to survive the influence of outside culture

c) Having the ability to accommodate outside culture

d) Fulfill the ability to give direction to cultural development

e) Have the ability to integrate or unite outside culture and native culture [22].

Based on the explanation above, local wisdom can be very influential in community life. By karen, it needs to be implemented and instilled early by choosing folklore or stories about local wisdom of certain regions that contain moral messages in it.

Education and moral development are important because with education and moral development, children can have selfdefense to stay away from negative things that can occur during their lifetime. In addition, the most important benefit of education and morals for children is to be able to develop moral values that are good in the child himself, so that he can independently, be able to distinguish between good (positive) and bad (negative) things. Without consistent learning, guidance and supervision from parents or other adults in the future, children should be able to determine all their behavior through actions in the positive sphere.

A positive specimen of moral development, better known today as prosocial behavior, is a major concern of early caregivers for children's social development [23]. Prosocial Behaviors are behaviors that reflects the concern or attention from child to child, for example, by helping, entertaining, or simply smiling at another child. The current study found that such caring behavior in response to other people's emotional changes was predicted by the quality of the relationship between teacher and child. Simply put, the more secure the child-teacher relationship, the more prosocial the child is towards his peers [24].

Moral behavior means behavior that is in accordance with the moral code of social groups. Whereas immoral behavior is behavior that deviates from the expectations of social groups. This behavior is not caused by ignorance of social expectations, but due to disagreement with social standards or lack of feeling requires adjustment. Immoral or non-moral behavior is caused more by indifference to the social group moral code than by the violation of group standards. Some of the wrong behaviors of early childhood are more amoral than immoral. Moral behavior is controlled by moral concepts or rules of conduct which are habits for members of a culture. Moral is related to: bad, right, wrong, self, belief, and community environment that underlies actions or thoughts. Children who have good moral development are hopeful that they should understand the right moral concepts and afterwards behave like these standards consistently.
Based on the discussion of the notion of moral values, it was concluded that moral values are valuable both according to the standards of logic, aesthetics, ethics, religion and law that are implemented in behavior, culture, customs, and customs according to the expectations of all members of the community group.

Whereas according to the program structure of the $\mathrm{K}$ safe children's activities in Kurikukulum 2013 concerning the development of indicators of moral values, a stimulus for the moral development of early childhood can be drawn, namely: 1) Familiarizing children with polite behavior. 2) Familiarize behaving in mutual respect. 3) Give understanding and guidance to children about attitudes so that children have noble behavior. 4) Give understanding to children about the differences in good and bad deeds. Where good deeds will be liked by others while bad deeds will not be liked by others. 5) Getting children to do useful activities. Based on the discussion of the stimulation of the development of moral values of early childhood, it was concluded that education, teaching, guidance, and habituation of activities with nuances of moral development were substantial for the development or the slow development of the moral values of early childhood.

Based on the explanation above, moral values are very important to stimulate in children. Moral values themselves have several stages of development ranging from $0-8$ years. It is the duty of adults to educate and stimulate the child's development.

\section{METHOD}

The research carried out is an experimental research that is by giving treatment to children. The research subjects were kindergarten children in Palu City. Data is collected through observation, documentation. In these activities, the researchers and educators are closely watched continuously to find out whether learning activities are carried out in practices that are in accordance with learning rules based on interests and principles of developing values of honesty, courage, and peace of love. according to the psychological development of children P Education A drain D U's son. The teacher uses a storytelling method that contains elements of local wisdom in it to improve the moral value of children with the composition of the initial observation activities (before treatment), treatment and final observation (after treatment).

Preparing Learning Activities. Preparation of learning activities by using: Learning media used in planting moral values using teaching aids in the form of folklore books illustrated, puppets, artificial objects, plants, pictures, VCD or videos. Using a handbook as a reference for teaching moral education, uses all kinds of books relating to moral education for early childhood. One of the books used is a booklet on moral development methods. 1) Implementing learning activity. Arrangement of playing environment. The playing environment is prepared depending on the learning plan that will be carried out. Then the playing tools and materials, tools and play materials are prepared according to the plan and purpose of learning and the age and development of the child. Besides that toys are also varied and as attractive as possible, 
the aim is to attract the attention of children. 2) Core Learning Activities. The teacher gives support to students, helps students who need help, and encourages students to try other ways so that children can be creative. Then collect the work of the child. Do not forget the teacher always reminds their students so that they do not forget to clean the game themselves. 3) Closing Activities. After the core activity is over, the teacher asks about the activities they have just done. The goal is to train children's memory and expand the vocabulary. 4) Observation of the results of activities [2]. Observation is carried out after all activities end by observing the work of the child and evaluating the shortcomings and strengths so that the activities that follow can be more effective.

\section{RESULTS AND DisCUSSION}

Data description is a description of the data obtained to support the discussion of the results of the study. through this picture you will see the initial and final conditions of each variable studied. Child moral value data that will be described consists of observational data of initial observation and final observation data. The preliminary observation data in this study took the form of observations made on children before being given treatment. The initial observation data aims to determine the child's early development, namely the moral value of the child before the experiment is applied while the final observation data is to see the final development after being given treatment.

Data below are described and taken moral values children from the results of initial observations and final observations on children. In summary, the results of observations of children's moral values are presented as follows:

TABLE I. Child Moral Value Data

\begin{tabular}{|c|c|c|}
\hline $\begin{array}{c}\text { Ability Description Children } \\
\text { Moral Values }\end{array}$ & $\begin{array}{c}\text { Early } \\
\text { Observation }\end{array}$ & $\begin{array}{c}\text { Final } \\
\text { Observation }\end{array}$ \\
\hline Mean & 65 & 95.00 \\
\hline St. Deviation & 15.45 & 14.55 \\
\hline High Value & 80 & 100 \\
\hline Low value & 45 & 80 \\
\hline
\end{tabular}

Based on the data table it can be concluded that the average value of the initial observation is 65 , whereas in the final observation the average value increases to 95.00. The tertiary value in the initial observation was 80 , while the final observation increased to 100 . Furthermore, the final value of the initial observation is 45 and the value is lower in the final observation, which is 80 .

According to the results of previous research, story books that focus on topics that are familiar with children, often related to home, family and pets, and things that become hobbies, will make children never get tired of hearing it when read [26]. This simple story book that contains folk tales and contains a moral message encourages children to share through storytelling by revealing the storyline, examining illustrations and making predictions. Telling a story could reshape the development of moral values and practice around storytelling, including relationships with educators who controls who can speak, what can the children say and how kids can say. Through this, children learn about the structure of stories, themes, traditional literature and plots [27].

Observed from the above opinion, it can be concluded that the story can develop children's development, especially the moral value of children. The learning method used by teachers in teaching and educating has a profound effect on the development of children's moral values. B story also contains elements of modeling (examples) that can be given to children through the story. As parents, they want children's attitudes and behaviors to have good morals [28]. Positive moral teaching in early childhood is not possible by giving long lectures and scolding if children make mistakes. One method that children enjoy without having to force it is to tell stories. In it parents can provide stories that contain moral elements and teach good moral values to children. Parsons argues that global children's literature can help young readers develop empathy for abandoned children throughout the world and at the same time help them recognize the universal nature of storytelling [29]. Agreeing with this view, storytelling adds to the wealth of communicative practices between individuals, such as encouragement to do good morals, supports the interpretation of self and others, and leads to appreciation for the opinions of others [30]. Through the storytelling method can develop a view towards human behavior and present universal experiences with the addition of values and manners through stories as examples of role models for children.

\section{CONCLUSION}

Based on the results of research and discussion, it can be concluded that the method of storytelling based on local wisdom is effective and significant towards the moral value of children aged 5-6 years. It is shown from the data gain score moral values of children having Sig $<\alpha(0.047<0.05)$ were mean gain score moral values of children in the experimental group sign ifikan and effectively using storytelling method based on local wisdom.

\section{REFERENCES}

[1]. Bayat, M. (2010). Use of dialogue journals and video-recording in early childhood teacher education. Journal of Early Childhood Teacher Education, 31(2), 159-172. doi:10.1080/10901021003781247

[2]. Bull, N. J. (2010). Moral Judgement From Childhood.

[3]. Pellizzoni, S., Siegal, M., \& Surian, L. (2010). The contact principle and utilitarian moral judgments in young children, 2, 265-270. doi:10.1111/j.1467-7687.2009.00851.x

[4]. Ambarwangi, S., \& Suharto, S. (2014). Reog As Means of Students' Appreciation and Creation in Arts and Culture Based on the Local Wisdom. Journal of Arts Research and Education, 14(1), 37-45. doi:10.15294/harmonia.v14i1.2789

[5]. Morelock, M. J., Brown, P. M., \& Morrissey, A. M. (2003). Pretend play and maternal scaffolding: Comparisons of toddlers with advanced development, typical development, and hearing impairment. Roeper 
Review, 26(1), 41-51. doi:10.1080/02783190309554238

[6]. Hakim, L., \& Dalli, C. (2016). "To be professional is a never-ending journey": Indonesian early childhood practitioners' views about the attitudes and behaviours of a professional teacher. Early Years, 5146(December), 1-14. doi:10.1080/09575146.2016.1256275

[7]. Sheridan, M., Howard, J., \& Alderson, D. (2010). Play in Early Childhood: From Birth to Six Years. Retrieved from https://books.google.com/books?hl=en\&lr=\&id=gvWsAgAAQBAJ\&p gis $=1$

[8]. Gülay Ogelman, H., Güngör, H., Körükçü, Ö., \& Erten Sarkaya, H. (2016). Examination of the relationship between technology use of 5-6 year-old children and their social skills and social status. Early Child Development and Care, $0(0), \quad 1-15$. doi:10.1080/03004430.2016.1208190

[9]. O'Connor, A., Nolan, A., Bergmeier, H., Hooley, M., Olsson, C., Cann, W., ... Skouteris, H. (2017). Early childhood education and care educators supporting parent-child relationships: a systematic literature review. Early Years, 37(4), 400-422. doi:10.1080/09575146.2016.1233169

[10]. Kim, Y. Y. (2016). A storytelling program to promote the social integration of multicultural groups in South Korea *, 1, 3-22.

[11]. Jirata, T. J. (2015). Positive Parenting, 10(2), 156-176.

[12]. Agosto, D. E. (2013). If I Had Three Wishes The Educational and Social / Emotional Benefits of Oral Storytelling, 9(1), 53-76.

[13]. Anak, P., \& Dini, U. (n.d.). 76 Peran Keluarga Dalam Menanamkan Nilai Moral Pada Anak Usia Dini......Wuri W.., 76-85.

[14]. Dahliani, D. (2015). Local wisdom in built environment in globalization era. International Journal of Education and Research, $3(6), 157-166$

[15]. Fajarini, U. (2014). Peranan Kearifan Lokal Dalam Pendidikan Karakter. SOSIO DIDAKTIKA: Social Science Education Journal, 1(2). doi:10.15408/sd.v1i2.1225

[16]. Mungmachon, M. R. (2012). Knowledge and Local Wisdom: Community Treasure. International Journal of Humanities and Social Science, 2(13), 174-181.

[17]. Purna, I. M. (2016). Kearifan lokal masyarakat desa Mbawa dalam mewujudkan toleransi beragama. Jurnal Pendidikan dan Kebudayaan, 1(2), 261-277.

[18]. Tina Kartika. (2014). Nonverbal Communication Study Human Behavior Reflection As Local Wisdom \n. IOSR Journal Of Humanities And Social Science (IOSR-JHSS), 19(11), 28-32.

[19]. Widodo, J. (2012). Urban Environment and Human Behaviour: Learning from History and Local Wisdom. Procedia - Social and Behavioral Sciences, 42(July 2010), 6-11. doi:10.1016/j.sbspro.2012.04.161

[20]. Kongprasertamorn, K. (2007). Local wisdom, environmental protection and community development: the clam farmers in Tambon Bangkhunsai Phetchaburi Province, Thailand. MANUSYA Journal of Humanities 10.1, 10(1), 1-10.

[21]. Agung, L. (2015). The Development of Local Wisdom-Based Social Science Learning Model with Bengawan Solo as the Learning Source. American International Journal of Social Science, 4(4), 51-58.
[22]. Huda, M., Jasmi, K. A., Mustari, I., Basiron, B., \& Sabani, N. (2017). Traditional wisdom on sustainable learning: An insightful view from Al-Zarnuji's Ta'lim al-Muta'allim. SAGE Open, 7(1). doi:10.1177/2158244017697160

[23]. Smetana, J. G., Rote, W. M., Jambon, M., Tasopoulos-chan, M., Villalobos, M., \& Comer, J. (2012). Developmental Changes and Individual Differences in Young Children's Moral Judgments, 83(2), 683-696. doi:10.1111/j.1467-8624.2011.01714.x

[24]. Anak, P., \& Dini, U. (n.d.). 196 strategi bercerita untuk menanamkan nilai moral pada anak usia dini, 196-206.

[25]. Lapsley, D. K., \& Narvaez, D. (2004). Moral Development, Self, and Identity. doi:10.1017/CBO9781107415324.004

[26]. Strategies, P. (2013). Practical Strategies Storytelling as Pedagogy, 21(2005).

[27]. Wood, C., Fredericks, M., Neate, B., \& Unghango, D. (2015). The stories we need to tell: Using online outsider-witness processes and digital storytelling in a remote Australian Aboriginal community, (4), 40-54.

[28]. Veronica, E., Silangit, B., Psikologi, F., Gadjah, U., \& Yogyakarta, M. (n.d.). Penggunaan storytelling untuk meningkatkan kesiapan untuk berubah pada karyawan use storytelling to increase readiness for change among telecommunication enterprise employees, 1-20.

[29]. Parsons, A., \& Howe, N. (2013). "This is Spiderman's mask." "no, it's green Goblin's": Shared meanings during boys' pretend play with superhero and generic toys. Journal of Research in Childhood Education, 27(2), 190-207. doi:10.1080/02568543.2013.766288 